\title{
CFA Or CFP: A Guide For Professors
}

Ronald L. Moy, St. John's University, USA

\begin{abstract}
The CFA Institute and the CFP Board of Standards provide professional certifications in the field of finance. In this paper, I provide my experience with the CFA and CFP programs in order to give other professors some insight into the process of attaining the designations. I hope to provide answers to some of the questions that other faculty members may have about attaining these professional designations and that my experiences will assist others in determining which, if either, of these designations to seek. This information may also be valuable to business school and economics professors who may be counseling students about these programs.
\end{abstract}

Keywords: Chartered Financial Analyst; Certified Financial Planner

\section{INTRODUCTION}

ood teaching requires that faculty members have credibility and the ability to connect with students. Although the doctorate gives professors the credibility, it rarely helps them to connect with students.

Because most students will not choose to pursue a doctorate, especially in the field of finance, where salaries and career opportunities have been so lucrative, the doctorate holds no special place for most students. Two credentials that many students will pursue, and hence have an interest in learning more about, are the Chartered Financial Analyst $\left(\mathrm{CFA}^{\circledR}\right)$ and Certified Financial Planner $\left(\mathrm{CFP}^{\circledR}\right)$ designations. Information on the two programs will allow faculty members to decide which designation, if either to pursue and to better advise students on how to attain the credentials.

In this paper, I provide an overview of both programs and try to share some of my experiences with both the CFA and CFP exams. By examining both professional designations, I hope to provide professors with information that will be beneficial in deciding whether to consider pursuing either designation and to assist professors in counseling students on the merits of both programs.

\section{OVERVIEW OF THE CFA PROGRAM}

In 1942, Benjamin Graham first proposed the need for a rating designation for financial analysts. Seventeen years later the National Federation of Financial Analysts Societies voted to form the Institute of Chartered Financial Analysts (ICFA) to provide a certification of competence in financial analysis. The ICFA was formally incorporated in 1961 and two years later, 284 candidates sat for the first CFA exam. Since that time, the popularity of the program has continued to grow with more than 90,000 candidates sitting for one of the three exams in June 2008.

The CFA Program is a self-study, graduate-level program for investment professionals. The three-year program requires the candidate to study for and pass three levels of exams. Passing the exams and meeting other requirements earns the CFA charter.

The curriculum for the program can be found in the Candidate Book of Knowledge (CBOK), which consists of ten areas of study and 89 topics. Table 1 provides a breakdown of the weights given to the different areas of study. Additional information about the CFA program can be found at http://cfainstitute.org/cfaprog/index.html. 
Table 1: Guideline Topic Area Weight for CFA Examination (percent)

\begin{tabular}{|l|c|c|c|}
\hline Topic Area & Level I & Level II & Level III \\
\hline Ethical \& Professional Standards (total) & $10-20$ & $5-15$ & $5-15$ \\
\hline Quantitative Methods & $7-17$ & $0-10$ & $0-10$ \\
\hline Economics & $5-15$ & $0-10$ & $0-10$ \\
\hline Financial Statement Analysis & $15-25$ & $15-25$ & 0 \\
\hline Corporate Finance & $3-13$ & $5-15$ & 0 \\
\hline Investment Tools (total) & $45-55$ & $35-45$ & $0-10$ \\
\hline Analysis of Equity Investments & $5-15$ & $20-30$ & $5-15$ \\
\hline Analysis of Fixed Income Investments & $5-15$ & $5-15$ & $5-15$ \\
\hline Analysis of Derivatives & $0-10$ & $0-10$ & $5-15$ \\
\hline Analysis of Alternative Investments & $0-10$ & 0 & $5-15$ \\
\hline Asset Valuation & $25-35$ & $35-45$ & $40-40$ \\
\hline Portfolio Management (total) & $0-10$ & $5-15$ & $35-45$ \\
\hline
\end{tabular}

\section{OVERVIEW OF THE CFP PROGRAM}

The CFP Board was founded in July 1985 as the International Board of Standards and Practices for Certified Financial Planners, Inc. (IBCFP) by the College for Financial Planning and the Institute of Certified Financial Planners. The IBCFP became the Certified Financial Planner Board of Standards Inc. on February 1, 1994. The CFP Board establishes and enforces education, examination, experience and ethics requirements for CFP certificants.

In June 1986, the CFP Board acquired ownership of the CFP and Certified Financial Planner marks from the College for Financial Planning as well as all responsibility for the testing and certification of CFP certificants. A Code of Ethics and Standards of Practice and Disciplinary Rules and Procedures were adopted that same year, and the other elements of the certification process, including: the registration of financial planning educational programs of institutions other than the College in 1987, continuing education requirements in 1988, and the delineation of experience requirements and certifying procedures in 1989, were then adopted.

In 1991, the CFP Board introduced a single comprehensive examination to test the integration and application of the knowledge gained from the program's personal financial planning curriculum. The program was modeled on the licensing examinations given to attorneys or Certified Public Accountants.

The CFP program covers seven basic areas of study. Table 2 provides a breakdown of the weights for the different topics in 1999 and 2004. Additional information about the CFP program can be found at http://www.cfp.net/become/.

Table 2: CFP Topics and Percentages 1999 and 2004

\begin{tabular}{|l|c|c|}
\hline \multicolumn{1}{|c|}{ Topic } & Percentage 1999 & Percentage 2004 \\
\hline General Principles of Financial Planning & $13 \%$ & $11 \%$ \\
\hline Insurance Planning \& Risk Management & $10 \%$ & $14 \%$ \\
\hline Employee Benefits Planning & $8 \%$ & $19 \%$ \\
\hline Investment Planning & $19 \%$ & $14 \%$ \\
\hline Income Tax Planning & $17 \%$ & $19 \%$ \\
\hline Retirement Planning & $18 \%$ & $15 \%$ \\
\hline Estate Planning & $15 \%$ & \\
\hline
\end{tabular}

\section{MY EXPERIENCE WITH THE EXAMS}

In the summer of 1996, I began the process of attaining the Chartered Financial Analyst designation. At the time, the three exams were given only once a year, at the beginning of June. However, in response to the growing demand, a second Level I exam was added in December of 2003. 
In order to encourage faculty members to seek the CFA designation, the CFA Institute offers scholarships to defray the cost of the program. Information on the scholarship programs is available at http://www.cfainstitute.org/cfaprog/university/professor_scholarship.html.

Once I received the reading list and study material in September, I began the nine-month process of preparing for the first exam. Preparation for the exam was quite straight forward given the detailed reading list and Learning Outcome Statements provided in the Candidate Book of Knowledge. My preparation began by obtaining as many of the books and articles as possible. Today, candidates receive several volumes of readings that contain all the readings for the program, many of which have been prepared specifically for the program. Throughout the next five months I devoted a substantial amount of time reading the material. I spent most of my time focusing on topics I was less familiar with, such as financial statement analysis and the CFA code of conduct. In January, I decided to add audio review tapes and a one booklet set of review notes and sample exams to my study regime. I chose two different providers for the material to add to the diversity of the study material. I found the tapes to be useful in reinforcing concepts and in providing exam study tips. Each year's tapes and study material are unique not only because a small amount of material for the exam changes from year to year, but because review providers attempt to predict the questions that are likely to appear on the exam. Test preparation services devote a great deal of time studying past exams and the frequency that certain types of questions appear. For example, during one study session, I was alerted to the fact that a certain financial statement analysis question was unlikely to appear on the coming exam because it appeared in the previous year's exam. The final two weeks before the exam were devoted to working through the previous years' exams. Given a successful outcome for the Level I exam, I was unwilling to fool with success, so I followed a similar approach for the Level II and III exams.

I took both the Level I and Level II exams on the campus of New York University in a regular classroom setting. Testing facilities clearly depend on the number of test takers and the facilities that are available. For the Level III exam, the tests were moved to the Jacob Javits Center, a large convention center in New York City. Chairs were placed in the large, cavernous convention hall, with different levels of the exam grouped together in the same room. This change of venue provided for a completely different, and in my opinion, less comfortable environment than I experienced with the previous exams.

Each exam consisted of two three hour sessions with an hour and a half break for lunch. Lunch was not provided, although in New York City, it was quite easy to find a place to get a quick bite to eat. Exam takers at other venues may find it more difficult to find somewhere to eat, as was the case when I took the CFP exam.

Results from the exam usually arrived in the mail by mid August and do not include the candidate's actual score and the grade required to pass the exam. Rather, exam results report three ranges of scores: less than 50 percent, between 51 and 70 percent or over 70 percent for each topic area on the exam. These results are presented to allow each candidate to evaluate his or her strengths and weaknesses. Given this information, it appears that the CFA Institute considers a score of less than 50 percent to be inadequate command of the material; a score between 50 and 70 percent to be adequate; and a score above 70 percent to be good command of the material. This can be useful in gauging the amount of knowledge that is necessary to pass the exam.

Once the exams are successfully completed, the candidate must meet the requirement of three years of experience (teaching in economics and finance can be used to fulfill the requirement,) join a local chapter of the CFA Institute and sign a professional conduct statement to attain the charter. Continuing education, although strongly encouraged, is not a requirement for maintaining the CFA designation. As of January 2007, there were more than 76,000 CFA charterholders from 126 countries.

For me, and I believe most professors teaching the standard courses in financial management, investments and portfolio management, the program, although a rather long and grueling process, is quite straightforward and consists of a large percentage of material that is familiar. The financial statement analysis portion of the exam was the most difficult for me and I suspect will be for many finance professors. In addition, the ethics and code of professional conduct is unique to the CFA program and cannot be ignored regardless of the candidate's knowledge of business ethics. 
A decade after sitting for the Level I CFA exam, I decided to try my hand at the Certified Financial Planner program. Unlike the CFA exam, the CFP exam is given regularly throughout the year in March, July and November. I began preparing for the July 2008 exam at the beginning of the year. One difficulty in preparing for the exam is the lack of a specific reading list. In order to sit for the CFP exam, candidates must meet an educational requirement that includes specific courses. However, a variety of professional or educational designations allow CFP candidates to waive the educational requirement. In my case, my CFA charter and my doctorate in economics both allowed me challenge status for the exams. Although saving me the time and trouble of doing course work, challenge status left me without textbooks and/or a reading list of the relevant topics. This left me struggling with what to study. I searched the CFP website for reading lists and texts, but I could find no such information. A general list of the topics covered on the exam is provided but was not easily translated into a study plan. To deal with this lack of direction, I decided to purchase study material. Although the study material for the CFA exam was helpful, I believe that the reading lists that are provided by the CFA Institute are sufficient to pass the exam. Colleagues of mine who have pursued the CFA designation have often times chosen to forgo the outside review material without any difficulty. However, the CFP program is another story. Without the review material, it is unlikely that I would have been able to prepare properly for the exam.

The exam consists of 10 hours of testing given on a Friday afternoon and Saturday. The Friday session consists of one four-hour exam. The Saturday session consists of two three-hour exams with a one hour break for lunch. I took the exams on the campus of the College of New Jersey in July 2008. As was the case for the CFA exams, lunch was not provided and because of the July date, the student center was closed on the weekends, making it difficult to obtain lunch during the limited break time. We were alerted by the CFP board that the student center would be closed for the Saturday session and most of us opted to brown bag it rather than leave the campus in search of lunch.

Unlike the CFA program, where the curriculum closely paralleled much of what I teach, the CFP program was filled with topics with which I had only limited familiarity. Trusts, income tax issues, retirement plans and estate planning are topics that are given little or no coverage in the standard finance courses. In many instances, I believe accounting and law professors may have greater familiarity with some of the topics in the CFP program than those of us who teach finance.

Exam results were received in the mail approximately eight weeks later. Unlike the CFA exam, no information was provided about the exam beyond a pass or fail.

Once a candidate has successfully completed the exam, he must meet the experience requirement (three years of full time experience $-2,000$ hour per year constitutes full time; those working part time need to meet the hourly requirements - teaching counts towards requirement), sign a professional conduct statement, and provide a college transcript verifying the attainment of a bachelor's degree. Continuing education is a requirement for maintaining the designation. The continuing education component requires 30 hours of continuing education, including two hours of ethics training from a certified provider every two years. Continuing education can be completed via live courses or through online providers. I completed the continuing education credits easily and inexpensively through an online provider. This provider allowed me to register for their entire catalog of CFP courses for a small flat fee (less than \$40) that allowed me access to the material for one year. This provider even reported my successful completion of each course directly to the CFP Board at no additional cost. As of February 2009, there were more than 58,000 CFP certificants in United States.

\section{CFA OR CFP?}

Terry and Vibhaker (2006) provide a comparative analysis of both the CFA and CFP programs. Their analysis includes a survey of individuals who hold both designations. Their survey included 272 usable responses. Of those responses, they found that $77 \%$ obtained the CFP certification prior to obtaining the CFA designation. Not surprisingly, the motivation for the majority of the individuals seeking the CFA or CFP designations was to broaden or deepen their knowledge of their respective field $(87.1 \%$ for the CFA, $73.9 \%$ or the CFP). The majority also sought the designations to establish professional credibility ( $83.8 \%$ for the CFA, $74.6 \%$ for the CFP). Respondents had differing views on the level of difficulty of the exams. In general, they viewed the CFA exams to be more 
challenging than the CFP exam with $97 \%$ believing that the CFA exams were either "very, or extremely challenging" and only $13.5 \%$ holding a similar belief of the CFP exam. However, since the CFP exam moved to a single comprehensive exam in 1991, the percentage of individuals that consider the CFP exam "not challenging" has decreased significantly, while the number that consider the exam "somewhat challenging" has increased significantly.

Both the CFA and CFP designations give financial professionals, as well as college professors, an opportunity to display a respected professional credential; but which designation is the right one to pursue? From my personal experience, I receive far more questions from students regarding the CFA program than the CFP program. There may be several reasons for this greater interest in the CFA program. First, I have displayed my CFA designation for nearly a decade and have devoted at least some class time to discussing the program. Second, my students may not be representative of students in other parts of the country due to my school's close proximity to Wall Street. Third, students may have greater familiarity with the CFP credential and may not feel the need to ask about the program. Finally, perhaps the CFA designation is held in higher esteem than the CFP designation. Several of the candidates for the CFP designation, whom I met while taking the exam, were surprised that a CFA charterholder would seek the CFP designation. Some of these individuals were well credentialed themselves, holding CPA licenses.

Whether a professor should counsel a student to pursue the CFA or CFP designation depends on the career goals of the student. Students that plan to pursue careers in personal finance, including the fields of life insurance, public accounting and law, may find the CFP program well suited to advancing their career. According to the CFP Board, more than 7,500 CFP certificants hold a CPA license, more than 1,600 are attorneys and more than 39,000 hold an insurance license. Although the CFA Institute has, in recent years, provided seminars on wealth management for wealthy individuals, the focus remains on financial analysis, and the CFP program is better suited to this type of work.

Students that plan to pursue careers in portfolio management and financial analysis will find the CFA designation more beneficial to these pursuits. The ideal candidate for the CFA program will likely be someone with strong quantitative skills and be interested in conducting economic and financial analysis.

Table 3 provides a comparison of the CFA and CFP programs.

\section{CONCLUSION}

Overall, I enjoyed both the Chartered Financial Analyst and Certified Financial Planner programs. Preparing for both forced me to fill gaps in my knowledge and to gain a different perspective on various topics. Both programs have provided me with the opportunity to connect with students through discussions about both programs. Through both programs, I have also gained the background to discuss issues that I have been able to bring to the classroom, such as ethics and professionalism, investment policy, and retirement and estate planning.

Many students and professors in the field of finance will find the CFA and the CFP programs as a way to gain credibility and enhance career opportunities. I believe most finance professors will find the curriculum and the level of rigor of the CFA program more in line with their professional pursuits. The type of consulting work and writing that a college professor is likely to engage in is more likely to benefit from holding the CFA designation. In addition, more opportunities seem to abound for professors who are CFAs. Textbook writing, consulting activities, and opportunities with the CFA Institute, such as writing or reviewing materials for the CFA program and the grading of CFA exams, are more in line with most professors' strengths and interests. Another benefit of holding the CFA charter is that full-time faculty members can sponsor students for scholarships for the Level I exam. For more information on the student scholarship program see,

http://www.cfainstitute.org/cfaprog/university/student_scholarship.html.

Undergraduate students, on the other hand, may find the CFP program provides greater opportunities. As business moves away from providing defined benefit pension plans to providing defined contribution plans, there will be a need for professionals to provide this type of counseling to individuals and to businesses that may be setting up these plans. In this case, the CFP program would be ideally suited for this type of career. On the other 
hand, students with strong quantitative backgrounds who are more interested in conducting financial analysis may find the CFA program more advantageous to their career. In either case, individuals who attain either designation are likely to broaden their knowledge in their chosen field and to gain an internationally respected credential.

Table 3: Comparison of CFA and CFP Programs

\begin{tabular}{|c|c|c|}
\hline Topic & CFA & CFP \\
\hline Accounting & $\begin{array}{l}\text { Focuses on financial statement analysis and the } \\
\text { comparison of financial performance of different } \\
\text { companies. Income taxes are only covered as they } \\
\text { relate to financial statement analysis. }\end{array}$ & $\begin{array}{l}\text { No discussion of financial statement analysis. Focuses on } \\
\text { income tax issues such as estate and gift taxes. }\end{array}$ \\
\hline Insurance & None & $\begin{array}{l}\text { Covered in detail and includes life insurance, disability } \\
\text { insurance, homeowners policies, etc. }\end{array}$ \\
\hline Estate Planning & None & $\begin{array}{l}\text { Covered in detail and includes income tax issues, wills and } \\
\text { trusts, and probate issues, etc. }\end{array}$ \\
\hline Retirement Planning & $\begin{array}{l}\text { Covered in the exam as it relates to investment policy } \\
\text { statements and portfolio allocations for a person near } \\
\text { or at retirement. }\end{array}$ & $\begin{array}{l}\text { Covered in detail and includes coverage of the different types } \\
\text { of defined benefit and defined contribution plans. }\end{array}$ \\
\hline Investments & $\begin{array}{l}\text { Detailed coverage including analysis of companies } \\
\text { and detailed coverage of derivatives, international } \\
\text { investing, etc. }\end{array}$ & $\begin{array}{l}\text { Covered briefly as an overview of the different types of } \\
\text { investment vehicles that are available to the individual. }\end{array}$ \\
\hline Ethics & Covered in detail. & Covered, but in less detail than the CFA program. \\
\hline Quantitative Analysis & $\begin{array}{l}\text { Includes regression, time series analysis and time } \\
\text { value of money. }\end{array}$ & Includes some time value of money. \\
\hline Reading List & $\begin{array}{l}\text { Extensive }- \text { and includes Learning Outcome } \\
\text { Statements to guide preparation. }\end{array}$ & $\begin{array}{l}\text { None. A topics list is available, but specific readings are not } \\
\text { assigned. }\end{array}$ \\
\hline Course Material & $\begin{array}{l}\text { Specifically prepared readings and prior year's } \\
\text { exams. }\end{array}$ & None for those who are exempt from the course requirements \\
\hline $\begin{array}{ll}\text { Third Party } & \text { Study } \\
\text { Material } & \end{array}$ & $\begin{array}{l}\text { Unnecessary if candidate covers the assigned readings } \\
\text { and the sample exams. }\end{array}$ & $\begin{array}{l}\text { Necessary because of the lack of a specific reading list and } \\
\text { sample exams. }\end{array}$ \\
\hline Required Course Work & None. The program is entirely self study. & $\begin{array}{l}\text { Yes, } 15 \text { semester credits or the equivalent in core topics. } \\
\text { Challenge status allows individuals to use certain credentials } \\
\text { to satisfy the educational requirement. These include: } \\
\text { Chartered Financial Consultant, Chartered Life Underwriter, } \\
\text { Chartered Financial Analyst, Ph.D. in business or economics, } \\
\text { Doctor of Business Administration, Licensed attorney - } \\
\text { inactive license acceptable and Licensed Certified Public } \\
\text { Accountant (CPA) - inactive license acceptable. There is also } \\
\text { a transcript review for individuals who have completed } \\
\text { courses through a non-CFP Board-Registered Program. To } \\
\text { meet the qualifications the candidate must demonstrate that } \\
\text { he has successfully completed equivalent upper-division } \\
\text { level college or university coursework at a regionally- } \\
\text { accredited college or university; and/or have one of the } \\
\text { credentials listed below that CFP Board has pre-approved for } \\
\text { partial credit towards the educational component. }\end{array}$ \\
\hline Exams & $\begin{array}{l}\text { Three exams consisting of two sessions each lasting } \\
\text { three hours. The Level I exam is given in June and } \\
\text { December. The Level II and III exams are only given } \\
\text { in June. }\end{array}$ & $\begin{array}{l}\text { The exam consists of three sessions given on a Friday and } \\
\text { Saturday. The Friday session consists of one four hour } \\
\text { afternoon session. Saturday sessions consist of two three } \\
\text { hour sessions. A total of } 285 \text { questions including one case in } \\
\text { each session and item set questions. Exam given in March, } \\
\text { July and November. }\end{array}$ \\
\hline Experience & $\begin{array}{l}3 \text { years of experience. Can be completed during or } \\
\text { after completing the exams. Teaching counts towards } \\
\text { requirement. }\end{array}$ & $\begin{array}{l}3 \text { years of full-time work experience }(2,000 \mathrm{hrs} . / \mathrm{yr} .) \text {. } \\
\text { Teaching counts towards requirement. }\end{array}$ \\
\hline Continuing Education & $\begin{array}{l}\text { Optional }-20 \text { hrs./yr. with } 2 \text { hrs. of ethics meets } \\
\text { requirement. Participants who meet the requirement } \\
\text { receive a letter verifying their participation. } \\
\text { Participants of the program for } 5 \text { yrs. are awarded a } \\
\text { certificate. Program is self study and self reported via } \\
\text { diary on the CFA Institute web site. The Financial } \\
\text { Analysts Journal and CFA Institute sanctioned events } \\
\text { list the number of continuing education credits that } \\
\text { the participant can report. }\end{array}$ & $\begin{array}{l}\text { Required - } 30 \text { hrs. every two years which includes } 2 \text { hrs. of } \\
\text { ethics training. Ethics component must be through a } \\
\text { certified provider. Requirements can be met via live courses } \\
\text { or online programs. Many online providers report } \\
\text { completion directly to the CFP Board. }\end{array}$ \\
\hline Student Scholarships & Yes for the Level I exam. & No \\
\hline Faculty Scholarships & Yes for all three exams. & No \\
\hline
\end{tabular}




\section{AUTHOR INFORMATION}

Ronald L. Moy is an associate professor of economics and finance in the Tobin College of Business at St. John's University. He received his Ph.D. in economics from Rutgers University. He is a Chartered Financial Analyst, a Certified Financial Planner and the co-author of the Irwin Guide to Stocks, Bonds, Futures and Options. E-mail: moyr@stjohns.edu

\section{REFERENCES}

1. Johnson, R.R. and J.R. Squires. "Into Our Fifth Decade," http://www.cfainstitute.org/cfaprog/overview/pdf/IntoOur5thDecade.pdf; accessed March 22, 2009.

2. CFA Institute Recognizes 7,736 New CFA Charterholders With Annual Global Announcement http://www.cfainstitute.org/aboutus/press/release/07releases/20070116_01.html; accessed March 22, 2009.

3. $\quad$ CFP® Certificant Profile http://www.cfp.net/media/profile.asp; accessed March 22, 2009.

4. CFP Exam Topics List from 2004 Survey, http://www.cfp.net/downloads/Financial\%20Planning\%20Topics\%202006.pdf; accessed March 22, 2009.

5. CFP Exam Topics List from 1999 Survey, http://www.cfp.net/downloads/guide FPTopics.pdf; accessed March 22, 2009.

6. Terry, A. and A. Vibhakar (2006). "A Comparative Analysis of the CFA and CFP Designations", Advances in Financial Education, Fall, pp. 66-81. 


\section{NOTES}

